\title{
Effects of feeding betaine-containing liquid supplement to transition dairy cows
}

\author{
A. P. A. Monteiro, ${ }^{\star}$ J. K. Bernard, ${ }^{*}$ J.-R. Guo, ${ }^{* 1}$ X-S. Weng, ${ }^{*}$ S. Emanuele, † R. Davis, † G. E. Dahl, $\ddagger$ and S. Tao ${ }^{* 2}$ \\ *Department of Animal and Dairy Science, University of Georgia, Tifton 31793 \\ †Quality Liquid Feeds, Dodgeville, WI 53533 \\ ‡Department of Animal Sciences, University of Florida, Gainesville 32611
}

\section{ABSTRACT}

Betaine is a natural compound found in sugar beets that serves as a methyl donor and organic osmolyte when fed to animals. The objective was to evaluate the effect of feeding betaine-containing molasses on performance of transition dairy cows during late summer in 2 trials. In early September, cows were randomly assigned to betaine (BET) or control $(\mathrm{CON})$ groups either shortly after dry off (trial $1 ; \mathrm{n}=10$ per treatment) or $24 \mathrm{~d}$ before calving (trial $2 ; \mathrm{n}=8$ per treatment) based on parity and previous mature equivalent milk yield. Cows were fed common diets supplemented either with a liquid supplement made of molasses from sugar cane and condensed beet solubles containing betaine $[\mathrm{BET}, 89.1 \mathrm{~g} / \mathrm{kg}$ of dry matter $(\mathrm{DM})]$ or a sugar cane molasses-based liquid supplement without betaine $(\mathrm{CON})$ until 8 wk postpartum. The liquid supplements had similar nutrient contents and were fed at a rate of 1.1 and $1.4 \mathrm{~kg} \mathrm{DM} / \mathrm{d}$ for pre- and postpartum cows, respectively. Starting at their entry in the studies, cows were housed in the same freestall barn without a cooling system. After calving, all cows were housed in the same barn cooled by misters and fans and milked thrice daily. Intake was recorded daily and body weight and body condition score were assessed every 2 wk. Milk yield was recorded at each milking and composition was analyzed weekly. Blood samples were collected weekly from a subset of cows to assess concentrations of metabolites and AA. No treatment effects were apparent for DM intake and body weight in the prepartum and postpartum periods. For cows enrolled at dry off, BET supported higher milk yield (45.1 vs. 41.9 $\mathrm{kg} / \mathrm{d}$ ) and fat content (4.78 vs. $4.34 \%$ ) and elevated plasma concentrations of nonesterified fatty acids and

\section{Received May 12, 2016.}

Accepted October 13, 2016.

${ }^{1}$ Current address: College of Animal Science and Veterinary Medicine, Heilongjiang Bayi Agricultural University, Daqing, China, 163319 .

${ }^{2}$ Corresponding author: stao@uga.edu $\beta$-hydroxybutyrate in early lactation compared to CON. However, no differences were observed for milk yield, most milk component contents and yields, and blood metabolites between treatments for cows enrolled during the close-up period. Compared to cows in the CON group, BET cows enrolled during the far-off period tended to have lower plasma concentrations of Met, Thr, and Trp during the pre- and postpartum periods. They also had lower plasma concentrations of Lys and Phe before calving but higher plasma Gly concentration after parturition. In conclusion, feeding a betainecontaining liquid supplement from far-off through early lactation improves lactation performance but increases adipose tissue mobilization and production of ketone bodies in early lactation.

Key words: betaine, dairy cow, milk production

\section{INTRODUCTION}

Betaine, also called trimethylglycine, is a natural compound either produced endogenously by choline oxidation (Zeisel, 2013) or found naturally in feed ingredients, such as sugar beet solubles, which have the most abundant betaine content (Eklund et al., 2005). Betaine has 2 main functions in an animal's body. It serves as an organic osmolyte, helping to reduce dehydration, stabilize protein structure, and preserve enzyme function when a cell is under osmotic stress. Additionally, it functions as a methyl donor when fed to animals and is a key component in one-carbon metabolism (Eklund et al., 2005; Bertolo and McBreairty, 2013). By providing the methyl group to the universal methyl donor, $S$-adenosylmethionine, through methionine, betaine influences many key functions in the body, such as growth, liver health, and lactation (Eklund et al., 2005; Ratriyanto et al., 2009).

In nonruminants, betaine has been used for several decades as a nutritional supplement to improve animal performance. In swine and poultry, betaine supplementation increases weight gain and feed efficiency and modifies the body composition by reducing the fat content and increasing the lean content of the carcass 
(Ratriyanto et al., 2009). Further, it also improves animal's resistance to diseases under nonoptimum raising conditions (Ratriyanto et al., 2009). In ruminants, betaine alters rumen fermentation (Mitchell et al., 1979) and improves nutrient digestibility (Wang et al., 2010). Similar to growing nonruminants, feeding betaine to lambs during the growing phase reduces subcutaneous fat thickness but does not change the weight gain or BW at slaughter (Fernández et al., 1998). In contrast, in finishing steers, supplementing betaine increases ADG as well as subcutaneous fat thickness (Bock et al., 2004). During lactation, feeding betaine also increases milk production of dairy cows (Wang et al., 2010; Peterson et al., 2012) and goats (Fernández et al., 2004). However, the effect of feeding betaine to transition dairy cows has never been studied. Thus, we hypothesized that feeding betaine-containing liquid supplement during the transition period would improve performance postpartum. The objective of the present study was to examine the effect of feeding betaine-containing liquid supplement from either far-off (trial 1) or close-up (trial 2) periods until $8 \mathrm{wk}$ postpartum on lactation performance and blood metabolites of multiparous Holstein dairy cows.

\section{MATERIALS AND METHODS}

\section{Animals, Experimental Design and Sampling}

This study was conducted at the Dairy Research Center of the University of Georgia-Tifton campus from September to December 2014. The Institutional Animal Care and Use Committee of the University of Georgia approved the animal handling and procedures before beginning the trial.

Beginning in early September, multiparous Holstein cows were randomly assigned to betaine (BET) or control $(\mathbf{C O N})$ groups either shortly after dry-off (trial 1; $60 \mathrm{~d}$ before expected calving, BET: $\mathrm{n}=10 ; \mathrm{CON}: \mathrm{n}=$ 10) or close-up (trial 2; $24 \mathrm{~d}$ before expected calving, BET: $\mathrm{n}=8$; CON: $\mathrm{n}=8$ ) based on their previous mature equivalent milk yield and parity. At the entry in the trials, the parity of BET and CON cows was 2.1 and $1.9(\mathrm{SEM}=0.2, P=0.51)$ for those enrolled during far-off and 2.7 and $2.4(\mathrm{SEM}=0.7, P=0.64)$ for those enrolled during close-up, respectively. Cows were fed common diets (Table 1) supplemented with molasses-based liquid supplements made from sugar cane $(\mathrm{CON})$ or from sugar cane and condensed beet solubles (BET) until $8 \mathrm{wk}$ in lactation. Both liquid supplements had similar DM ( $70.4 \%)$, CP $(\sim 39.9 \%$ of $\mathrm{DM})$, and $\mathrm{NE}_{\mathrm{L}}(\sim 1.95 \mathrm{Mcal} / \mathrm{kg}$ of $\mathrm{DM})$, but only the one fed to BET cows contained betaine $(89.1 \mathrm{~g} / \mathrm{kg}$ of
DM). Diets were formulated to provide 1.1 and $1.4 \mathrm{~kg}$ $\mathrm{DM} / \mathrm{d}$ of liquid supplement for dry and lactating cows, respectively, resulting in $9.98,10.18$, and $5.17 \%$ of DM feeding rate of liquid supplements in the far-off, closeup, and lactating cow diets, respectively (Table 1). Following their entry in trials either at dry-off or close-up, cows were housed in the same dry or lactating pens during the pre- and postpartum periods, respectively. The pen for milking cows had a cooling system, but dry cows were only provided with shade. The cooling system for lactating cows included foggers attached to the front face of fans over the feed bunks and free stalls. Fans ran continuously whenever ambient temperature was above $18.3^{\circ} \mathrm{C}$, and foggers were activated whenever ambient relative humidity was below $85 \%$.

\section{Sample Collection and Analyses}

To evaluate the environmental heat stress, the ambient temperature and relative humidity in the barn were measured by Hobo Pro Series Temp probes (Onset Computer Corp., Pocasset, MA) every 15 min and the temperature-humidity index (THI) was calculated based on Dikmen et al. (2008): THI $=(1.8 \times \mathrm{T}+32)$ $-[(0.55-0.0055 \times \mathrm{RH}) \times(1.8 \times \mathrm{T}-26)]$, where $\mathrm{T}=$ air temperature $\left({ }^{\circ} \mathrm{C}\right)$ and $\mathrm{RH}=$ relative humidity $(\%)$. Cows were weighed every 2 wk and at calving, and the BCS was evaluated at the same time by the same individual. After calving, cows were milked 3 times (0800, 1600 , and $2400 \mathrm{~h}$ ) each day, and the milk weight at each milking was recorded electronically (Alpro, DeLaval, Kansas City, MO). Milk samples were collected weekly from 3 consecutive milkings using bronopol-B-14 as a preservative to analyze milk concentrations of fat, protein, lactose, SNF, MUN, and SCC by Dairy One Cooperative (Ithaca, NY) using a Foss 4000 instrument (Foss North America, Eden Prairie, MN).

Cows were individually fed once a day at $1400 \mathrm{~h}$ during the dry period and at $0900 \mathrm{~h}$ during lactation. Daily DMI was measured by Calan Gate system (American Calan Inc., Northwood, NH) during the entire experimental period. Dietary ingredients and TMR were sampled 3 times each week to determine the DM content, and rations were adjusted to account for any changes in DM content of each ingredient. The TMR samples were composited every 2 wk and ground to pass through a 1-mm screen using a Wiley mill (Thomas Scientific, Swedesboro, NJ) and analyzed (Table 2) for ash, CP, ADF, NDF adjusted for ash, sugar, and starch by Cumberland Valley Analytical Services (Hagerstown, MD), and ether extract (AOAC International, 2000).

Blood samples were collected from coccygeal vessels into sodium-heparinized Vacutainers (Becton Dickin- 
son, Franklin Lakes, NJ) weekly and at calving from a subset of animals that were enrolled during either far-off (BET: $\mathrm{n}=6$; CON: $\mathrm{n}=6$ ) or close-up (BET: $\mathrm{n}=6$; CON: $\mathrm{n}=6$ ). The same animals were sampled at each time. Samples were immediately put in ice and then centrifuged at $2,619 \times g$ for $30 \mathrm{~min}$ at $4^{\circ} \mathrm{C}$ to collect plasma. Colorimetric methods were used to measure plasma concentrations of glucose (Autokit Glucose; Wako Chemicals USA, Inc., Richmond, VA), nonesterified fatty acids (NEFA; HR Series NEFAHR(2), Wako Chemicals USA, Inc.), and BHB (Autokit 3-HB, Wako Chemicals USA, Inc.), and the inter- and intra-assays CV were 6.2 and $8.5 \%, 7.0$ and $3.4 \%$, and 4.8 and $4.2 \%$, respectively. Additionally, the AA profile of plasma samples collected at -5 and 5 wk relative to calving from a subset (BET: $\mathrm{n}=5$; CON: $\mathrm{n}=5$ ) of cows enrolled during the far-off period were determined by the methods described by Deyl et al. (1986).

\section{Statistical Analyses}

Because cows were managed differently during the far-off period, data from cows enrolled during far-off or close-up were analyzed separately. The GLM procedure of SAS was used to analyze parity, treatment length, dry period and gestation lengths, and calf birth weight. The MIXED procedure of SAS was used to analyze the repeated measures data including DMI, BW, BCS, milk yield and composition, and plasma metabolites. The statistical model included fixed effects of treatment, time, and treatment by time with cow nested in the treatment as the random effect. For milk yield analysis, the mature equivalent milk yield of the previous lactation was included in the SAS model as a covariate. Plasma AA concentrations were analyzed by the MIXED procedure of SAS, and the SAS model included fixed effects of treatment, time, and treatment by time with cow (treatment) as the random effect. Data are reported as least squares means \pm standard error of the mean. Significance and tendency were declared when $P$ $\leq 0.05$ and $0.05<P \leq 0.10$, respectively.

\section{RESULTS}

\section{THI, Treatment, Gestation Length, and Calf Birth Weight}

All cows calved from September through November 2014, during which time the THI in the dry cow pen averaged $62.8(\mathrm{SD}=11.2)$, suggesting that the environmental condition had minimal effects in this study. For those enrolled during far-off, the average prepartum treatment length for BET and CON cows were 59.4 and
Table 1. Ingredient composition of TMR fed to cows during prepartum and postpartum periods

\begin{tabular}{|c|c|c|c|}
\hline Ingredient, $\%$ of DM & Far-off & Close-up & Lactating \\
\hline Corn silage & - & 20.37 & 30.17 \\
\hline Ryegrass silage & - & - & 9.05 \\
\hline Sorghum silage & 32.93 & 20.37 & - \\
\hline T85 Bermudagrass silage & 21.96 & 8.15 & 1.72 \\
\hline Brewers grains, wet & 5.99 & 4.07 & 12.07 \\
\hline Ground corn & 8.14 & 11.20 & 18.28 \\
\hline Liquid supplement $^{1}$ & 9.98 & 10.18 & 5.17 \\
\hline Megalac $^{2}$ & - & - & 1.72 \\
\hline Whole cottonseed & - & - & 2.16 \\
\hline Corn gluten feed & - & - & 3.45 \\
\hline Citrus pulp & - & 4.07 & 3.45 \\
\hline Soybean hulls, pelleted & 11.98 & 4.07 & 1.29 \\
\hline Urea & - & - & 0.17 \\
\hline Soybean meal & 6.75 & 4.07 & 1.29 \\
\hline Amino plus ${ }^{3}$ & - & 5.46 & 1.72 \\
\hline Prolak $^{4}$ & - & - & 3.02 \\
\hline Calcium carbonate & 0.40 & 1.22 & 0.96 \\
\hline Salt, white & 0.24 & - & 0.17 \\
\hline Sodium bicarbonate & - & - & 0.86 \\
\hline Magnesium oxide & 0.32 & - & 0.34 \\
\hline Potassium-magnesium-sulfate & - & - & 0.09 \\
\hline Availa $4^{5}$ & 0.08 & 0.08 & 0.03 \\
\hline Vitamin E, 20,000 IU/454 g & 0.20 & 0.20 & 0.03 \\
\hline Rumensin, ${ }^{6} 3 \mathrm{~g} / 454 \mathrm{~g}$ & 0.40 & 0.41 & 0.26 \\
\hline OmniGen-AF & 0.50 & 0.51 & 0.22 \\
\hline Smartamine $\mathrm{M}^{8}$ & - & 0.12 & - \\
\hline Animate $^{9}$ & - & 5.30 & - \\
\hline Trace mineral-vitamin premix $^{10}$ & 0.14 & 0.14 & 0.14 \\
\hline
\end{tabular}

$\overline{{ }^{1} 28 \% \text { CP molasses-based liquid supplement made from sugar cane or }}$ made from molasses from sugar cane and condensed beet solubles containing betaine.

${ }^{2}$ Calcium salts of long-chain fatty acids, Arm Hammer Animal Nutrition, Church \& Dwight Co. Inc. (Princeton, NJ).

${ }^{3}$ Ruminally protected soybean meal, Ag Processing Inc. (Omaha, NE). ${ }^{4}$ Marine and animal RUP supplement, H. J. Baker \& Bros. Inc. (Westport, CT).

${ }^{5}$ Organic zinc, manganese, copper, and cobalt, Zinpro Corporation (Eden Prairie, MN).

${ }^{6}$ Elanco Animal Health (Indianapolis, IN.)

${ }^{7}$ Immune stimulant, Prince Agri Products Inc. (Quincy, IL).

${ }^{8}$ Encapsulated Methionine, Adisseo (Alpharetta, GA).

${ }^{9}$ Anionic mineral supplement, Prince Agri Products Inc.

${ }^{10}$ Mineral-vitamin premix contained (DM basis): $26.1 \% \mathrm{Ca} ; 0.38 \% \mathrm{Mg}$; $1.76 \% \mathrm{~S} ; 144 \mathrm{mg} / \mathrm{kg} \mathrm{Co} ; 9,523 \mathrm{mg} / \mathrm{kg} \mathrm{Cu} ; 1,465 \mathrm{mg} / \mathrm{kg} \mathrm{Fe} ; 842 \mathrm{mg} / \mathrm{kg}$ I; $28,617 \mathrm{mg} / \mathrm{kg} \mathrm{Mn;} 220 \mathrm{mg} / \mathrm{kg}$ Se; $25,343 \mathrm{mg} / \mathrm{kg} \mathrm{Zn;} \mathrm{4,210,830} \mathrm{IU/}$ $\mathrm{kg}$ vitamin A; 1,684,330 IU/ $\mathrm{kg}$ vitamin D; 21,045 IU/ $\mathrm{kg}$ vitamin E.

$57.8 \mathrm{~d}(\mathrm{SEM}=1.6 \mathrm{~d}, P=0.48)$, respectively, and no differences $(P>0.4)$ were observed in dry period length (61.6 vs. $60.0 \mathrm{~d}$ for BET and CON cows, respectively; SEM $=1.6 \mathrm{~d})$ or gestation length $(281.5$ vs. $279.9 \mathrm{~d}$ for BET and CON cows, respectively; $\mathrm{SEM}=1.6 \mathrm{~d}$ ). However, BET cows tended $(P=0.07)$ to give birth to heavier calves compared to CON cows (43.1 vs. 38.9 $\mathrm{kg}$, SEM $=1.6 \mathrm{~kg}$ ). When treatments started during the close-up period, BET and CON cows had similar $(P>0.30)$ prepartum treatment length $(24.4$ vs. 23.2 $\mathrm{d}$, respectively; SEM $=1.6 \mathrm{~d})$, dry period length (55.9 
vs. $54.8 \mathrm{~d}$, respectively; $\mathrm{SEM}=1.6 \mathrm{~d}$ ), gestation length ( 278.8 vs. 277.5 d, respectively; $\mathrm{SEM}=1.6 \mathrm{~d}$ ), and calf birth weight (35.7 vs. $38.3 \mathrm{~kg}$, respectively; $\mathrm{SEM}=1.7$ $\mathrm{kg})$.

\section{Milk Yield and Composition}

Feeding diets supplemented with betaine-containing liquid supplement from far-off to 8 wk postpartum increased $(P<0.05)$ milk yield, milk fat percentage, and FCM, and tended $(P=0.06)$ to decrease milk lactose percentage in early lactation compared to CON (Table $3)$. No differences $(P>0.15)$ were observed for concentrations of milk protein, SNF, MUN, or SCS (Table 3). However, due to the higher milk yield, BET supported higher $(P \leq 0.05)$ milk protein and fat yield relative to CON (Table 3). In contrast, for cows that started to receive experimental diets from close-up period, no treatment effects $(P>0.20)$ were observed for milk yield, FCM, concentrations of milk fat, protein, SNF, and yields of milk components (Table 4). Compared to CON cows, BET cows tended $(P=0.08)$ to have a higher milk MUN concentration (Table 4) and higher $(P<0.01)$ concentration of milk lactose at 1 wk after calving (treatment by time interaction: $P<0.01$ ). A treatment by time interaction also existed for milk SCS $(P=0.05)$, but the PDIFF functions of SAS indicated time effects within each treatment rather than treatment effects at individual time points.

\section{DMI, BW, BCS, Energy Balance, Feed Efficiency, and Blood Metabolites}

Regardless of the time that treatments started (faroff or close-up), no differences $(P>0.10)$ were seen between treatments for DMI, BW, BCS, feed efficiency, and plasma concentration of metabolites from pre- to postpartum period (Tables 3 and 4). A treatment by time interaction $(P=0.01)$ was observed for BCS of cows enrolled during close-up, such that BET cows had a lower $(P<0.01)$ BCS at 4 wk after calving compared with CON cows. Cows fed BET throughout the entire dry period tended $(P=0.09)$ to have a lower energy balance during early lactation compared with CON cows (Table 3). A treatment by time interaction $(P$ $=0.03$ ) existed for plasma NEFA concentration and a tendency $(P=0.08)$ of treatment by time interaction for plasma concentrations of BHB for cows enrolled during the far-off period, such that BET cows had higher concentrations of NEFA and BHB in early lactation compared with CON cows (Figure 1).

\section{Plasma AA}

The AA profile of plasma samples were only measured for cows enrolled during the far-off period. Compared to CON cows, BET cows tended $(P<0.10)$ to have lower plasma concentrations of Met, Thr, and Trp at both -5 and 5 wk relative to calving (Table $5)$. Interactions $(P \leq 0.02)$ of treatment by time were

Table 2. Nutrient contents (DM basis; means \pm SD) of the experimental diets with (BET) or without (CON) betaine

\begin{tabular}{|c|c|c|c|c|c|c|}
\hline \multirow[b]{2}{*}{ Item } & \multicolumn{2}{|c|}{ Far-off } & \multicolumn{2}{|c|}{ Close-up } & \multicolumn{2}{|c|}{ Lactating } \\
\hline & $\operatorname{BET}(\mathrm{n}=3)$ & $\mathrm{CON}(\mathrm{n}=3)$ & $\operatorname{BET}(\mathrm{n}=5)$ & $\mathrm{CON}(\mathrm{n}=5)$ & $\operatorname{BET}(\mathrm{n}=9)$ & $\mathrm{CON}(\mathrm{n}=9)$ \\
\hline $\mathrm{CP}, \%$ & $18.8 \pm 2.1$ & $19.0 \pm 0.7$ & $19.4 \pm 1.0$ & $18.5 \pm 1.3$ & $15.3 \pm 0.6$ & $15.3 \pm 0.7$ \\
\hline $\mathrm{SP}^{1} \%$ & $7.4 \pm 0.2$ & $7.3 \pm 1.3$ & $8.0 \pm 1.0$ & $7.7 \pm 0.9$ & $5.0 \pm 0.4$ & $5.0 \pm 0.4$ \\
\hline $\mathrm{NDFa}^{2}, \%$ & $44.7 \pm 2.1$ & $44.3 \pm 1.7$ & $35.3 \pm 2.2$ & $35.1 \pm 3.2$ & $34.5 \pm 1.7$ & $33.3 \pm 1.6$ \\
\hline $\mathrm{ADF}, \%$ & $28.9 \pm 0.0$ & $29.6 \pm 1.3$ & $22.3 \pm 1.5$ & $21.7 \pm 2.1$ & $20.3 \pm 1.0$ & $20.0 \pm 1.0$ \\
\hline Starch, \% & $10.5 \pm 1.5$ & $10.6 \pm 1.5$ & $16.5 \pm 1.2$ & $16.7 \pm 2.3$ & $25.5 \pm 1.7$ & $27.5 \pm 0.9$ \\
\hline Sugar, \% & $3.3 \pm 1.0$ & $3.1 \pm 0.4$ & $4.0 \pm 1.0$ & $3.9 \pm 0.6$ & $2.3 \pm 0.6$ & $1.8 \pm 0.4$ \\
\hline Ether extract, $\%$ & $2.6 \pm 0.4$ & $2.2 \pm 0.1$ & $2.9 \pm 0.5$ & $3.0 \pm 0.5$ & $4.9 \pm 0.6$ & $4.4 \pm 0.5$ \\
\hline $\mathrm{NFC},{ }^{3} \%$ & $26.4 \pm 4.6$ & $25.9 \pm 2.4$ & $36.3 \pm 1.9$ & $37.5 \pm 0.3$ & $39.3 \pm 2.3$ & $41.0 \pm 0.7$ \\
\hline Ash, $\%$ & $8.8 \pm 0.9$ & $8.2 \pm 0.8$ & $7.6 \pm 0.7$ & $8.0 \pm 0.3$ & $7.2 \pm 0.4$ & $6.8 \pm 0.5$ \\
\hline $\mathrm{NE}_{\mathrm{L}}{ }^{4} \mathrm{Mcal} / \mathrm{kg}$ & 1.41 & 1.41 & 1.43 & 1.43 & 1.65 & 1.65 \\
\hline MP supplied, ${ }^{4} \mathrm{~g} / \mathrm{d}$ & 896 & 896 & 1,030 & 1,030 & 2,995 & 2,995 \\
\hline MP balanced, ${ }^{4} \mathrm{~g} / \mathrm{d}$ & 6 & 6 & 15 & 15 & 22 & 22 \\
\hline Lys, ${ }^{4} \%$ of MP & 6.36 & 6.36 & 6.41 & 6.41 & 5.54 & 5.54 \\
\hline Lys balanced, ${ }^{4} \mathrm{~g} / \mathrm{d}$ & 9.0 & 9.0 & 10.7 & 10.7 & -41.5 & -41.5 \\
\hline Met, ${ }^{4} \%$ of MP & 2.00 & 2.00 & 2.85 & 2.85 & 1.93 & 1.93 \\
\hline Met balanced, ${ }^{4} \mathrm{~g} / \mathrm{d}$ & 2.2 & 2.2 & 11.4 & 11.4 & -15.1 & -15.1 \\
\hline Lys:Met ${ }^{4}$ & 3.18 & 3.18 & 2.25 & 2.25 & 2.87 & 2.87 \\
\hline
\end{tabular}

${ }^{1} \mathrm{SP}=$ soluble protein.

${ }^{2} \mathrm{NDFa}=$ ash-free $\mathrm{NDF}$.

${ }^{3} \mathrm{NFC}, \%=100-(\% \mathrm{NDF}+\% \mathrm{CP}+\%$ ether extract $+\%$ ash $)(\mathrm{NRC}, 2001)$.

${ }^{4}$ Calculated using Cornell Net Carbohydrate and Protein System, version 6.5 (Van Amburgh et al., 2015). 
Table 3. The BW; BCS; DMI; feed efficiency (FE); plasma concentration of glucose, BHB, and nonesterified fatty acids (NEFA); energy balance in early lactation; milk yield and milk composition for cows fed diets with (BET, $\mathrm{n}=10)$ or without $(\mathrm{CON}, \mathrm{n}=10)$ betaine from the far-off period to 8 wk after calving

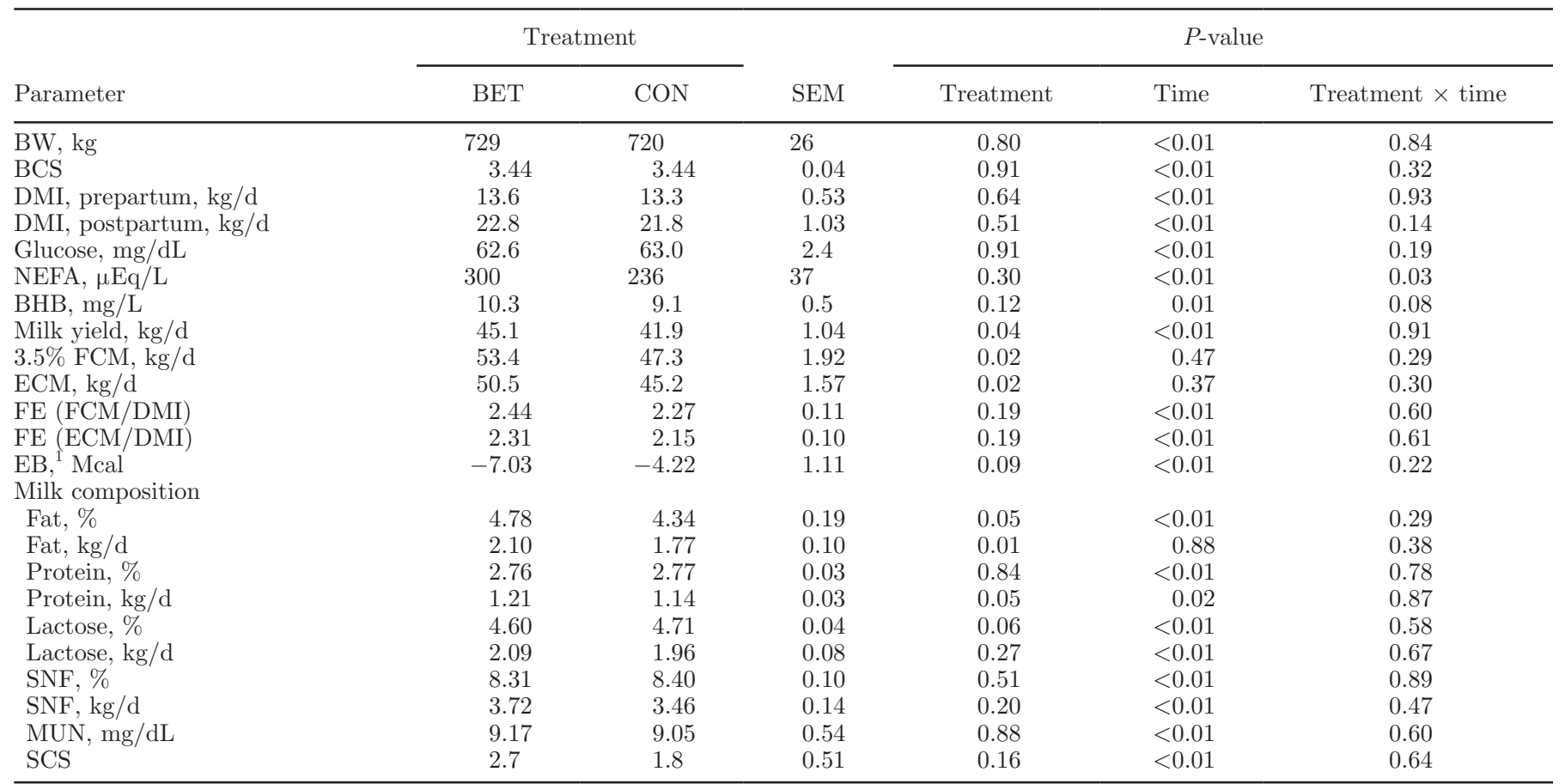

${ }^{1}$ Energy balance during early lactation.

Table 4. The BW: BCS; DMI; feed efficiency (FE); plasma concentrations of glucose, BHB, and nonesterified fatty acids (NEFA); energy balance in early lactation; and milk yield and milk composition for cows fed diets with $(\mathrm{BET}, \mathrm{n}=8)$ or without $(\mathrm{CON}$, $\mathrm{n}=8)$ betaine from the close-up period until 8 wk after calving

\begin{tabular}{|c|c|c|c|c|c|c|}
\hline \multirow[b]{2}{*}{ Parameter } & \multicolumn{2}{|c|}{ Treatment } & \multirow[b]{2}{*}{ SEM } & \multicolumn{3}{|c|}{$P$-value } \\
\hline & $\mathrm{BET}$ & $\mathrm{CON}$ & & Treatment & Time & Treatment $\times$ time \\
\hline DMI, prepartum, kg/d & 13.7 & 13.8 & 0.94 & 0.93 & $<0.14$ & 0.53 \\
\hline DMI, postpartum, $\mathrm{kg} / \mathrm{d}$ & 22.2 & 21.9 & 1.41 & 0.89 & $<0.01$ & 0.94 \\
\hline Glucose, $\mathrm{mg} / \mathrm{dL}$ & 59.1 & 61.5 & 3.8 & 0.67 & 0.01 & 0.89 \\
\hline Milk yield, kg/d & 43.2 & 40.9 & 2.06 & 0.46 & $<0.01$ & 0.81 \\
\hline $3.5 \%$ FCM, $\mathrm{kg} / \mathrm{d}$ & 46.6 & 45.9 & 2.88 & 0.86 & 0.04 & 0.50 \\
\hline $\mathrm{ECM}, \mathrm{kg} / \mathrm{d}$ & 44.8 & 44.2 & 2.53 & 0.86 & 0.06 & 0.41 \\
\hline $\mathrm{FE}(\mathrm{FCM} / \mathrm{DMI})$ & 2.15 & 2.07 & 0.14 & 0.68 & $<0.01$ & 0.80 \\
\hline $\mathrm{FE}(\mathrm{ECM} / \mathrm{DMI})$ & 2.08 & 1.99 & 0.11 & 0.58 & 0.01 & 0.66 \\
\hline $\mathrm{EB},{ }^{1}$ Mcal & -4.57 & -4.18 & 1.59 & 0.86 & $<0.01$ & 0.89 \\
\hline \multicolumn{7}{|l|}{ Milk composition } \\
\hline Lactose, $\mathrm{kg} / \mathrm{d}$ & 2.03 & 1.90 & 0.10 & 0.38 & $<0.01$ & 0.15 \\
\hline SNF, $\%$ & 8.53 & 8.39 & 0.11 & 0.36 & $<0.01$ & 0.56 \\
\hline $\mathrm{SNF}, \mathrm{kg} / \mathrm{d}$ & 3.62 & 3.44 & 0.17 & 0.45 & $<0.01$ & 0.24 \\
\hline MUN, mg/dL & 9.61 & 8.15 & 0.56 & 0.08 & 0.97 & 0.89 \\
\hline SCS & 2.6 & 2.9 & 0.7 & 0.75 & 0.25 & 0.05 \\
\hline
\end{tabular}

${ }^{1}$ Energy balance during early lactation. 
1068
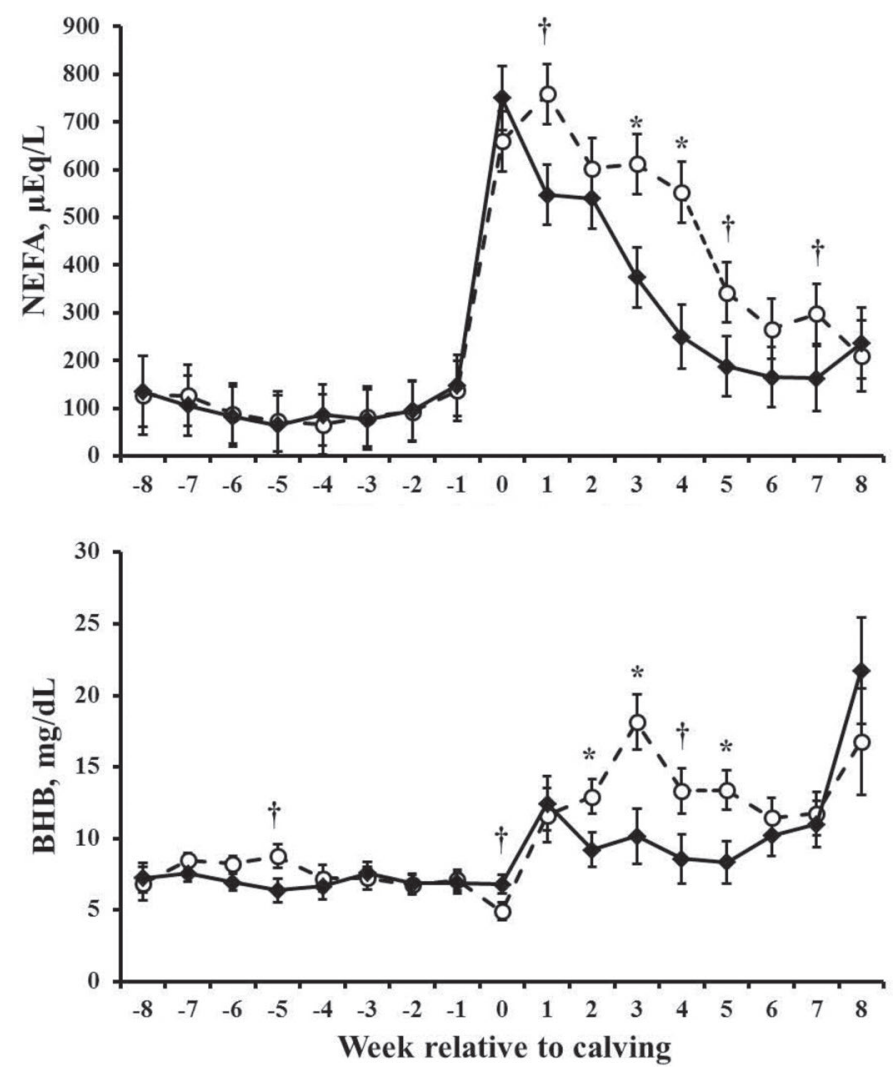

Figure 1. Plasma concentrations of nonesterified fatty acids (NEFA) and BHB of cows fed diets with (BET, $\mathrm{O}, \mathrm{n}=6$ ) or without $(\mathrm{CON}, \diamond, \mathrm{n}=6)$ betaine from far-off period until 8 wk after calving In the NEFA analysis, effect of treatment $(P=0.30)$, time $(P<0.01)$ and treatment by time interaction $(P=0.03)$. In the BHB analysis, effect of treatment $(P=0.12)$, time $(P<0.01)$, and treatment by time interaction $(P=0.08)$. Error bars represent SEM. ${ }^{*} P<0.05$, $\dagger P \leq 0.10$.

observed for plasma Lys, Phe, and Gly concentrations, such that BET cows had lower Lys and Phe concentrations at -5 wk relative to calving but higher plasma levels of Gly at 5 wk postpartum compared to $\mathrm{CON}$ cows (Table 5). A treatment by time interaction was also found for plasma histidine concentration, but the PDIFF functions of SAS indicated a time effect of CON cows such that they had higher histidine at -5 wk than 5 wk relative to calving, rather than treatment effect at either time points.

\section{DISCUSSION}

Betaine has various functions in an animal's body. In nonruminants, it has been used for several decades as a nutritional supplement to modify the body composition of the animal (Eklund et al., 2005), and because of that, it is called body fat modifier. However, research regarding the use of betaine as a nutritional approach in ruminants, especially in dairy cattle, is relatively less extensive compared with swine and poultry, possibly because of the microbial degradation in the rumen. Under in vivo conditions, the turnover rate of betaine in the rumen is approximately $45 \% / \mathrm{h}$, and it disappears from the rumen 4 to $6 \mathrm{~h}$ after feeding (Mitchell et al., 1979). In contrast, when incubated with rumen fluid in vitro, the disappearance rate of betaine is much slower, such that 70 to $75 \%$ of betaine remains in the rumen fluid after $4 \mathrm{~h}$ of incubation (Mitchell et al., 1979; Löest et al., 2001). The large difference in the disappearance rate of betaine between the in vitro and in vivo studies may indicate faster rumen degradation in vivo, but it also suggests that a portion of the betaine may escape the microbial degradation and pass through the rumen without being degraded. Studies suggest that the amount of betaine supplemented may significantly affect its effectiveness on milk yield. During mid to late lactation, supplementation of rumen unprotected betaine increases cow's milk yield only when the feeding rate is greater than or equal to $100 \mathrm{~g} / \mathrm{d}$ per cow (Wang et al., 2010; Peterson et al., 2012), but the amount of betaine escaping ruminal degradation is unknown. In the current study, the feeding rate of betaine was $1.29,1.32$, and $0.67 \%$ of the DM in far-off, close-up, and lactating diets, respectively, which provided more than $100 \mathrm{~g} / \mathrm{d}$ of supplemented betaine per cow during the entire experimental period. Therefore, a significant amount of betaine may have escaped rumen degradation and entered the small intestine.

In the current study, inclusion of a liquid supplement containing betaine in the diets from far-off to early lactation increased milk yield by $7.7 \%(3.24 \mathrm{~kg} / \mathrm{d})$ and milk fat content by $10.1 \%$ (0.44\%) during the first $8 \mathrm{wk}$ of lactation compared with CON, resulting in a greater increase in FCM by $12.9 \%$ (6.1 kg/d). In contrast, when cows were supplemented only from close-up to early lactation, milk yield did not differ between treatments, suggesting that the length of supplementation during the dry period may play an important role in the positive effect of betaine on subsequent milk yield, but the reasons are unknown. In the current study, the different length of the treatments between cows enrolled during the far-off and close-up periods should not be a limiting factor for betaine to exert effect on performance. In mid-lactation cows, a short period of supplementation (7-15 d) of rumen unprotected betaine increases milk yield (Wang et al., 2010; Peterson et al., 2012; Hall, 2014). In contrast, feeding rumen protected betaine $(45 \mathrm{~g} / \mathrm{d})$ in early lactation in a Met-deficient diet for 9 wk had no effect on cows' performance (Davidson et al., 2008), suggesting that either the amount of betaine supplemented was not enough or the effect of betaine is diminished when it is fed with a diet deficient in Met 
during early lactation. In the current study, the lactating diets were balanced by MP and the amount of Met was lower than the requirement (Table 2), which, however, still cannot explain the distinct effects of betaine feeding length during the dry period on following milk production. Therefore, it may be critical to supplement betaine during both the entire dry period and early lactation to gain the improvement in milk yield. The mechanism of the positive effect of supplementing betaine from far-off to early lactation on milk production is not clear. Wang et al. (2010) report improved nutrient digestibility of mid-lactation cows fed betaine, which may enhance cows' productivity, but this possibility cannot explain the lack of difference in milk yield between BET and CON cows enrolled during the close-up period in the current trial. As an organic osmolyte, betaine stabilizes and maintains the function and activity of proteins and enzymes in a cell, especially during stress (review by Craig, 2004). Further, it facilitates the maintenance of cellular osmolarity and reduces the energy cost of ion pumping in a cell, promoting cell proliferation (Review by Cronjé, 2005). Thus, longterm feeding of betaine during the dry period may promote prepartum mammary growth, which in turn results in an increase in subsequent milk production. However, we cannot exclude the possibility that the relatively small animal number per treatment for those enrolled during the close-up period prevents us from observing a difference in milk yield. Future studies with a higher number of animals are warranted to confirm the results obtained in the current study. Nevertheless, in the present study, the lack of differences in most of the parameters measured for cows enrolled at the start of the close-up period indicates that feeding betaine containing molasses from close-up to early lactation has a negligible influence on cow performance. Therefore, the following discussion will focus on the cows that received treatments starting from far-off period, unless specifically indicated.

Cows fed a betaine-containing diet had higher milk fat content compared to $\mathrm{CON}$ cows, consistent with previous reports in lactating cows (Wang et al., 2010) and primiparous lactating dairy goats (Fernández et al., 2004) but in contrast with Peterson et al. (2012), who reported that feeding betaine to mid-lactation cows has no effect on milk fat content. The higher concentration of milk fat observed in the present study may be due to the higher plasma NEFA concentrations in early lactation, which provides more substrate and increases the proportion of preformed fatty acid taken up by the mammary gland. However, we cannot rule out a direct effect of feeding betaine on mammary fat synthesis. Feeding betaine promotes ruminal acetate synthesis (Mitchell et al., 1979) and improves nutrient digestibility (Wang et al., 2010), suggesting an altered rumen fermentation, which may in turn influence mammary fatty acid synthesis. Fernández et al. (2004) reported that feeding betaine to lactating goats increased the

Table 5. Plasma AA concentrations of cows fed diets with $(\mathrm{BET}, \mathrm{n}=5)$ or without $(\mathrm{CON}, \mathrm{n}=5)$ betaine from far-off to 8 wk after calving

\begin{tabular}{|c|c|c|c|c|c|c|c|c|}
\hline \multirow{2}{*}{$\mathrm{AA}$} & \multicolumn{4}{|c|}{ Week relative to calving } & \multirow{2}{*}{$\mathrm{SEM}^{2}$} & \multirow{2}{*}{\multicolumn{3}{|c|}{$P$-value }} \\
\hline & \multicolumn{2}{|c|}{-5} & \multicolumn{2}{|c|}{5} & & & & \\
\hline \multicolumn{9}{|l|}{$\mathrm{EAA}, \mu \mathrm{g} / \mathrm{mL}$} \\
\hline Arginine & 12.59 & 12.50 & 11.22 & 11.39 & 0.79 & 0.97 & 0.09 & 0.84 \\
\hline Histidine & 8.89 & 9.74 & 8.16 & 7.35 & 0.57 & 0.98 & $<0.01$ & 0.01 \\
\hline Lysine & 11.75 & 15.83 & 10.40 & 9.91 & 1.25 & 0.29 & $<0.01$ & 0.02 \\
\hline Methionine & 3.11 & 3.56 & 2.13 & 2.65 & 0.19 & 0.06 & $<0.01$ & 0.81 \\
\hline Phenylalanine & 7.50 & 8.52 & 6.63 & 6.12 & 0.35 & 0.58 & $<0.01$ & 0.01 \\
\hline Threonine & 8.44 & 10.55 & 10.03 & 11.46 & 0.78 & 0.09 & 0.08 & 0.60 \\
\hline Tryptophan & 4.75 & 5.62 & 5.09 & 5.61 & 0.30 & 0.09 & 0.47 & 0.42 \\
\hline \multirow{2}{*}{\multicolumn{9}{|c|}{$\mathrm{NEAA}^{1}{ }^{1} \mu \mathrm{g} / \mathrm{mL}$}} \\
\hline & & & & & & & & \\
\hline Glycine & 10.65 & 14.00 & 34.77 & 27.40 & 2.16 & 0.37 & $<0.01$ & 0.02 \\
\hline Proline & 6.21 & 7.38 & 13.86 & 10.95 & 1.54 & 0.99 & $<0.01$ & 0.20 \\
\hline Serine & 6.86 & 7.57 & 9.58 & 10.05 & 0.71 & 0.45 & $<0.01$ & 0.86 \\
\hline Tyrosine & 8.06 & 9.78 & 6.33 & 7.03 & 0.61 & 0.10 & $<0.01$ & 0.40 \\
\hline
\end{tabular}

${ }^{1}$ Cysteine was not detectable. 
proportions of short-chain fatty acid in milk fat, suggesting an increase in de novo fatty acid synthesis. The lack of difference in milk protein percentage is similar to others (Davidson et al., 2008; Wang et al., 2010), but different from Peterson et al. (2012), who report lower milk protein percentage in mid-lactation cows fed betaine. The higher yield of milk protein with BET compared to $\mathrm{CON}$ is the result of the higher milk yield and is consistent with the lower plasma concentrations of Met, which is a limiting AA for milk protein synthesis (NRC, 2001). BET cows had a lower milk lactose percentage but similar plasma glucose concentrations compared with CON cows, suggesting a lower rate of mammary lactose synthesis. In contrast, for those enrolled during the close-up period, relative to CON cows, BET cows had a higher milk lactose concentration at 1 wk after calving. The reasons for the different results of the effect of betaine on milk lactose percentage between cows enrolled during far-off and close-up periods are unknown but suggest dietary betaine may alter mammary gland lactose synthesis. Similar to other studies in dairy cows (Davidson et al., 2008; Peterson et al., 2012) and goats (Fernández et al., 2004), supplementing betaine has no effect on SCS, indicating no influence on mammary health.

Consistent with previous studies in mid-lactation cows (Wang et al., 2010; Peterson et al., 2012), DMI, BW, BCS, and plasma glucose concentration did not differ between treatments during both pre- and postpartum periods for cows receiving treatments starting from far-off period. However, for those enrolled at close-up, BET cows had lower BCS at 4 wk after calving, suggesting more body fat mobilization relative to CON cows. However, because of the small number of animals, the BCS data need to be interpreted with caution. Compared with CON cows, those that received betaine had higher plasma NEFA and BHB concentrations in early lactation, which is consistent with the more severe negative energy balance and suggests an enhanced adipose tissue mobilization and greater nutrient demand due to the greater milk synthesis. However, the increase in plasma NEFA may raise a concern of development of fatty liver in the early lactation of cows supplemented with betaine. In the liver, betaine is a product of choline oxidation (Zeisel, 2013) and serves as a methyl donor for endogenous synthesis of Met and the following production of the universal methyl donor, $S$-adenosylmethionine (Bertolo and McBreairty, 2013). Therefore, supplementing betaine may spare choline and provide $S$-adenosylmethionine for phosphatidylcholine synthesis through 1,2-diacylglycerol cholinephosphotransferase pathway and phosphatidylethanolamine $N$-methyltransferase pathway, respectively (Cole et al., 2012), which may in turn promote the synthesis of very low-density lipoprotein and hepatic fat export. For example, inclusion of betaine in the diet of rats prevented the development of fatty liver induced by a high-fat diet (Deminice et al., 2015) or ethanol feeding (Kharbanda et al., 2007). Whether feeding betaine can reduce the hepatic fat accumulation in early lactation cows is unknown but deserves further investigation.

In addition to the effect on hepatic fatty acid metabolism, betaine is an important substrate for de novo synthesis of Met through the betaine-homocysteine methyltransferase pathway in the liver (Bertolo and McBreairty, 2013), thus theoretically sparing Met. Because of the lack of differences in performance and blood metabolites measured for cows enrolled at the start of the close-up period, only the plasma samples collected from cows that received treatments starting from the far-off period were analyzed for AA profiles. The samples collected at $5 \mathrm{wk}$ before calving were analyzed to examine the effect of feeding betaine during the early dry period on plasma AA profiles in the middle of dry period when the mammary gland starts to grow (Capuco et al., 1997) and the fetus is rapidly growing. Further, to avoid the influence of active muscle mobilization during the first 3 wk of lactation on plasma AA concentrations (Overton et al., 1998), plasma samples subjected to AA analyses were collected at 5 wk postpartum. We expected that BET cows would have higher plasma Met because of the potential Met sparing effect of betaine compared with CON cows. However, surprisingly, BET cows tended to have lower plasma concentrations of Met, Thr, and Trp during both pre- and postpartum periods compared with CON cows. Further, plasma levels of Lys and Phe were lower for BET relative to CON cows only during the dry period. These lower levels of EAA in BET compared to CON cows during the prepartum period may be due to a greater muscle deposition in the fetus, as suggested by the higher calf birth weight, and potentially improved mammary growth, as indicated by the higher milk yield. Similarly, feeding betaine to gestating sows increases the birth weight and muscle content of the offspring (Jia et al., 2015). The lower Met, Thr, and Trp concentrations in the plasma of BET cows in early lactation support the higher milk protein yield relative to CON cows. Moreover, the higher plasma Gly concentration in BET cows during the postpartum period may indicate the involvement of betaine in hepatic 1-carbon metabolism. In the liver, betaine can be demethylated by betaine-homocysteine methyltransferase to form methionine and dimethylglycine, which in turn is converted to glycine by flavoprotein dimethylglycine dehydrogenase and mitochondrial sarcosine dehydrogenase. Therefore, the higher plasma concentration of glycine in BET cows may suggest that dietary betaine provides methyl groups for remethyl- 
ation of homocysteine in liver, sparing Met in early lactation, when a greater amount of this amino acid is needed for milk protein synthesis

\section{CONCLUSIONS}

Feeding a liquid supplement containing betaine from far-off period through early lactation increased milk yield, milk fat percentage, and FCM, but it did not affect DMI. Consequently, cows fed BET had enhanced adipose tissue mobilization and production of ketone bodies compared with CON cows, suggesting an adaptive response to support the higher milk synthesis. Additionally, relative to CON cows, BET cows had lower plasma concentrations of Met and other EAA, which reflects the greater demand for fetal growth and mammary gland development and synthesis. In contrast, feeding betaine from the close-up period to early lactation had no effect on cow performance, indicating the importance of feeding betaine during the entire dry period. Therefore, inclusion of betaine-containing liquid supplement in the diets from far-off period to lactation can be an effective approach to improve cow performance during early lactation. However, additional research is needed to examine the effect of feeding betaine during the transition period on metabolic health.

\section{REFERENCES}

AOAC International. 2000. Official Methods of Analysis. 17th ed. AOAC International, Arlington, VA.

Bertolo, R. F., and L. E. McBreairty. 2013. The nutritional burden of methylation reactions. Curr. Opin. Clin. Nutr. Metab. Care 16:102-108.

Bock, B. J., J. R. Brethour, K. R. Harmoney, and S. R. Goodall. 2004 Influence of betaine on pasture, finishing, and carcass performance in steers. Prof. Anim. Sci. 27:395-401.

Capuco, A. V., R. M. Akers, and J. J. Smith. 1997. Mammary growth in Holstein cows during the dry period: Quantification of nucleic acids and histology. J. Dairy Sci. 80:477-487.

Cole, L. K., J. E. Vance, and D. E. Vance. 2012. Phosphatidylcholine biosynthesis and lipoprotein metabolism. Biochim. Biophys. Acta 1821:754-761.

Craig, S. A. S. 2004. Betaine in human nutrition. Am. J. Clin. Nutr. 80:539-549.

Cronjé, P. B. 2005. Heat stress in livestock-The role of the gut in its aetiology and a potential role for betaine in its alleviation. Recent Adv. Anim. Nutr. Aust. 15:107-122.

Davidson, S., B. A. Hopkins, J. Odle, C. Brownie, V. Fellner, and L. W. Whitlow. 2008. Supplementing limited methionine diets with rumen-protected methionine, betaine, and choline in early lactation Holstein cows. J. Dairy Sci. 91:1552-1559.

Deminice, R., R. P. da Silva, S. G. Lamarre, K. B. Kelly, R. L. Jacobs, M. E. Brosnan, and J. T. Brosnan. 2015. Betaine supplementation prevents fatty liver induced by a high-fat diet: Effects on onecarbon metabolism. Amino Acids 47:839-846.
Deyl, Z., J. Hyanek, and M. Horakova. 1986. Profiling of amino acids in body fluids and tissues by means of liquid chromatography. J. Chromatogr. 379:177-250.

Dikmen, S., E. Alava, E. Pontes, J. M. Fear, B. Y. Dikmen, T. A. Olson, and P. J. Hansen. 2008. Differences in thermoregulatory ability between slick-haired and wild-type lactating Holstein cows in response to acute heat stress. J. Dairy Sci. 91:3395-3402.

Eklund, M., E. Bauer, J. Wamatu, and R. Mosenthin. 2005. Potential nutritional and physiological functions of betaine in livestock. Nutr. Res. Rev. 18:31-48.

Fernández, C.. L. Gallego, and C. J. Lopez-Bote. 1998. Effect of betaine on fat content in growing lambs. Anim. Feed Sci. Technol. 73:329-338.

Fernández, C., P. Sanchez-Seiquer, A. Sanchez, A. Contreras, and J. M. de la Fuente. 2004. Influence of betaine on milk yield and composition in primiparous lactating goats. Small Rumin. Res. $52: 37-43$

Hall, L. W. 2014. The evaluation of dietary betaine, pre and probiotics, transitional substrates, and B-mercaptoacetate on physiological, metabolic, hormonal and production responses in lactating Holstein cows subjected to thermal stress. PhD Dissertation. University of Arizona, Tucson.

Jia, Y., H. Song, G. Gao, D. Cai, X. Yang, and R. Zhao. 2015. Maternal betaine supplementation during gestation enhances expression of mtDNA-encoded genes through D-loop DNA hypomethylation in the skeletal muscle of newborn piglets. J. Agric. Food Chem. 63:10152-10160.

Kharbanda, K. K., M. E. Mailliard, C. R. Baldwin, H. C. Beckenhauer, M. F. Sorrell, and D. J. Tuma. 2007. Betaine attenuates alcoholic steatosis by restoring phosphatidylcholine generation via the phosphatidylethanolamine methyltransferase pathway. J. Hepatol. 46:314-321.

Löest, C. A., E. C. Titgemeyer, J. S. Drouillard, D. A. Blasi, and D. J. Bindel. 2001. Soybean hulls as a primary ingredient in forage-free diets for limit-fed growing cattle. J. Anim. Sci. 79:766-774.

Mitchell, A. D., A. Chappell, and K. L. Knox. 1979. Metabolism of betaine in the ruminant. J. Anim. Sci. 49:764-774.

NRC. 2001. Nutrient Requirements of Dairy Cattle. 7th rev. ed. Natl. Acad. Press, Washington, DC.

Overton, T. R., J. K. Drackley, G. N. Douglas, L. S. Emmert, and J. H. Clark. 1998. Hepatic gluconeogenesis and whole-body protein metabolism of periparturient dairy cows as affected by source of energy and intake of the prepartum diet. J. Dairy Sci. 81(Suppl. 1):295.

Peterson, S. E., P. Rezamand, J. E. Williams, W. Price, M. Chahine, and M. A. McGuire. 2012. Effects of dietary betaine on milk yield and milk composition of mid-lactation Holstein dairy cows. J. Dairy Sci. 95:6557-6562.

Ratriyanto, A., R. Mosenthin, E. Bauer, and M. Eklund. 2009. Metabolic, osmoregulatory and nutritional functions of betaine in monogastric animals. Asian-australas. J. Anim. Sci. 22:1461-1467.

Van Amburgh, M. E., E. A. Collao-Saenz, R. J. Higgs, D. A. Ross, E. B. Recktenwald, E. Raffrenato, L. E. Chase, T. R. Overton, J. K. Mills, and A. Foskolos. 2015. The Cornell Net Carbohydrate and Protein System: Updates to the model and evaluation of version 6.5. J. Dairy Sci. 98:6361-6380.

Wang, C., Q. Liu, W. Z. Yang, J. Wu, W. W. Zhang, P. Zhang, K. H. Dong, and Y. X. Huang. 2010. Effects of betaine supplementation on rumen fermentation, lactation performance, feed digestibilities and plasma characteristics in dairy cows. J. Agric. Sci. 148:487-495.

Zeisel, S. H. 2013. Metabolic crosstalk between choline/1-carbon metabolism and energy homeostasis. Clin. Chem. Lab. Med. 51:467475 . 